\title{
What Technology Startups Must Get Right to Globalize Early and Rapidly Tony Bailetti
}

\author{
"Do not confine your children to your own learning," \\ for they were born in another time. \\ Chinese proverb
}

\begin{abstract}
Upon or shortly after inception, growth-oriented technology startups must operate in a market that is global. Management teams and investors of technology startups can benefit from approaches and models that can help them operate in a global market early and rapidly. How well a technology startup addresses the realities of globalization will determine its success. A better understanding of what management teams and investors of technology startups must get right to globalize their startups is needed. This article is an attempt to meet this need.

In this article, lessons that have been extracted from six literature streams and from information on 21 startups founded in 12 countries are used to identify the six elements that a startup must get right to globalize early and rapidly. These six elements are: i) Problem scope, ii) Stakeholders' commitments, iii) Collaborative entrepreneurship, iv) Relational capital, v) Legitimacy, and vi) Global capability. The main contribution of this article is that it throws the spotlight on the need to develop prescriptive rules and practitioner-oriented models that can help a technology startup operate globally from an early stage.
\end{abstract}

\section{Introduction}

What must a management team get right to globalize a technology startup early and rapidly? How can a management team fill the gap between their startup's need to successfully operate in a globally integrated market and their startup's lack of resources and skills?

Technology startups that globalize early and rapidly will win over those that do not. The earlier a startup globalizes, the stronger will be its capability for exploiting growth-seeking opportunities worldwide. Early globalization increases a company's adaptability to uncertain environments and its willingness to change (Sapienza et al., 2006; tinyurl.com/8exd7hq). Managers globalize a technology startup early and rapidly to: i) increase the value of the startup, ii) reduce revenue source risks, and iii) increase the size of the startup's addressable market.
Over the last 20 years, scholars have contributed various perspectives to explain the early and rapid involvement of startups in international markets. However, conventional approaches used to globalize technology startups take too long, cost too much, increase stakeholders' risks, and waste the passion of many talented people who develop innovative products and services. It is therefore time to help managers of technology startups meet the demands of global markets early and rapidly.

The objective of this article is to help the management teams of technology startups and their investors to identify what they need to get right to globalize their companies (i.e., address the needs of a global market), early and rapidly. The article provides a set of key messages extracted from the literature, and it develops six elements (i.e., building blocks) into a unified model on how to globalize new technology ventures early and rap- 


\section{What Technology Startups Must Get Right to Globalize Early and Rapidly}

\section{Tony Bailetti}

idly. In addition to entrepreneurs, management teams, and investors, academics, service providers, managers of economic development organizations, and policy makers can also benefit from a better understanding of the implications that these approaches and models have for the ways in which they currently support regional and local economic development.

For the purpose of this article, internationalization refers to the process by which a company increases its involvement in cross-border markets via exporting, licensing, partnerships, joint ventures, direct foreign investment, or other means. Globalization refers to the process by which a company meets the needs of a global market, one which integrates many formerly domestic markets including the company's home market. A global market is the result of nation-states breaking down barriers to international trade, shifts to market economies, mobility of talent and capital, and advances in transportation, information, and communications technology.

Messages that were extracted from six literature streams are presented and then applied to the globalization of startups. These messages are targeted at management teams and investors. Next, the method used to identify startups that grew foreign sales early and rapidly is described and the results of applying the method are provided. Then, three lessons learned from examining the publicly available information about the startups in the sample are discussed and the elements of the architecture for rapid globalization are proposed. The last section provides the conclusions.

\section{Messages from Examining the Literature}

The scholarly work most relevant to a startup's early and rapid globalization can be organized into six literature streams:

\section{Rapid internationalization}

2. International new ventures

3. Effectuation logic

4. Global startups

5. Gradual internationalization process models

6. Internalization theory of the multinational enterprise and the ownership-location-internalization (OLI) model
For each of the literature streams, the following subsections provide a summary, identify key publications examined, and contribute key messages for management teams and investors of technology startups extracted by the author from his examination of the literature. Appendix A provides the references examined to extract these lessons learned.

\section{Stream 1: Rapid internationalization}

Contributors to the rapid internationalization literature stream seek to identify the factors that affect: i) time before starting to internationalize (e.g., first export, license, foreign direct investment, or joint venture), ii) percentage of foreign sales at a given age, and iii) number of countries or regions in which the company operates at a given age.

The key messages of the rapid internationalization literature stream for the management teams and investors of startups include:

1. Define and act on what can be achieved using the means that are available to the startup (e.g., personal contacts, international experiences) and collaborate with others.

2. Proactively leverage new and existing networks to locate and interact with potential international customers and partners.

3. Secure commitments to act jointly and quickly, develop new knowledge, and increase relational trust with partners in lead markets who have technology knowledge that overlaps with the startup's technology knowledge.

4. Collaborate and partner with well-established system integrators and distributors that offer global reach and low risk of channel conflicts.

5. Select large customers with global reach whose requirements can be satisfied quickly.

6. Build and leverage relationships with customers, suppliers, and partners - and a large and diverse number of members of their networks - then, quickly deliver value to them.

7. Use the Internet to market the startup's products and services. 


\section{What Technology Startups Must Get Right to Globalize Early and Rapidly}

\section{Tony Bailetti}

8. Increase legitimacy by: i) establishing presence in key markets, ii) gaining high-profile endorsements from established local companies, iii) leveraging mentors and advisors to build an ecosystem around the startup, and iv) participating in high-profile activities related to direct foreign investment.

9. Develop knowledge-intensive products and build strong capability to market and sell them.

10. Leverage the network of relational capital associated with the startup's management team and ensure that the network members are committed to assisting with early and rapid internationalization.

11. Increase the startup's i) social capital; ii) ability to acquire, assimilate, transform, and exploit external knowledge; and iii) knowledge (i.e., the content of what is learned).

\section{Stream 2: International new venture}

The international new venture literature stream seeks to explain the start of the internationalization process, not how internationalization proceeds once it has started. Contributors to this literature stream argue that gradual internationalization processes do not fully explain the early and rapid internationalization of startups. Contributors to this literature stream focus on the entrepreneur's role in launching and growing a multicountry enterprise.

The key messages of the international new venture stream for the management teams and investors of startups include:

1. Lock the startup into a global growth path from its inception. Internationalize early to concurrently increase the startup's value, develop capabilities to grow globally, and reduce revenue source risks.

2. Leverage what was learned servicing previous markets when entering a new foreign market.

3. Increase the entrepreneur's international competences, vision, risk tolerance, cross-border networks, and awareness of foreign growth opportunities.

4. Create value through cross-border resource combinations.
5. Invest in increasing the knowledge-intensity of the startup's resources and embed the startup in the system that creates the knowledge that is critical to its success.

6. Avoid internalizing all the resources required to expand internationally; use governance mechanisms such as those found in joint ventures or licensing agreements to acquire the resources needed.

\section{Stream 3: Effectuation logic}

Contributors to the effectuation logic literature stream apply the effectuation theory developed by Sarasvathy (2001: tinyurl.com/cmjpnxg; 2008: tinyurl.com/c2zknnj) to examine companies early in their internationalization process and the entrepreneurs decision regarding internationalization.

The effectuation logic differs from causation logic. According to Sarasvathy (2001, tinyurl.com/cmjpnxg), causation logic means that the end is given and the focus is on selecting the means to achieve the end. Effectuation logic means that the means are given and the focus is on what can be achieved with them.

Effectuation questions the traditional neo-classical economic assumptions of how individuals think and behave when starting a business (Perry et al., 2011; tinyurl.com/cs56bcb). Effectuation theory offers to better explain why startups internationalize early and rapidly despite lacking information on the host market, international experience, and resources. Effectuation examines early and rapid internationalization of startups at the individual, company, and network levels.

The key messages of effectuation theory applied to the study of startups that internationalize early include:

1. Behave as if causation and effectuation logics are not two opposite concepts; for example, effectuation logic can be used to explore opportunities, whereas causation logic can be used to exploit opportunities.

2. Use effectuation logic to identify opportunities with foreign actors when resources are lacking.

3. Using causation logic to create international new ventures primarily results in export-type entry modes, not equity-type entry modes. 


\section{What Technology Startups Must Get Right to Globalize Early and Rapidly}

\section{Tony Bailetti}

4. Using effectuation logic to create international new ventures results in multiple entry modes.

5. Once the business grows and the number of foreign partners increases, causation logic should be used rather than effectuation logic, even when the startup is still small.

6. Use causation logic to overcome psychic distance (tinyurl.com/8huqvik).

7. Acquisition of global knowledge and international experience can follow internationalization; it does not have to precede it.

8. Selection of markets to enter is not controlled by psychic distance or cultural differences.

9. Entry strategies based on an entrepreneur's knowledge, links to foreign markets, and cooperative arrangements with network partners do not necessarily require formal market research to be carried out by the startup itself.

\section{Stream 4: Global startups}

The literature on global startups - organizations designed to operate in a globally integrated market from inception - is emerging. It focuses more on innovating by learning from the world than on building an efficient network of production, sales, and subsidiaries that can penetrate markets around the world.

The key messages for the management teams and investors of startups include:

1. Engage in the exchange of knowledge, information, and other resources with international contacts to recognize and exploit opportunities on the global market.

2. Create value by searching out and mobilizing untapped technology and market knowledge scattered around the world.

3. Adjust to changes in knowledge required during the global startup process in terms of classification, function, network composition, and interaction patterns.

\section{Stream 5: Gradual internationalization process models}

The product-operations-market (POM) model and the Uppsala model explain how the internationalization process proceeds after it has started. These two models were developed by examining how companies with an existing history gradually intensify their activities in foreign markets. Entry into foreign markets is an incremental process that starts late in a company's life cycle; early internationalization increases the probability of company failure.

The key messages of the gradual internationalization process models literature stream for the management teams and investors of startups include:

1. Enter foreign markets only after gaining experience operating in the domestic market and acquiring knowledge about the targeted foreign market.

2. Once ready to go global, shed domestic rigidities for the purpose of exploiting global opportunities.

3. Expand internationally to learn about foreign markets as well as the startup's own internal capabilities.

4. Investments made in one region cannot easily be deployed in other regions.

5. Distinguish between specific foreign-market knowledge and general knowledge on how to internationalize.

Stream 6: Internalization theory of the multinational enterprise and the OLI model

Internalization is a general principle that explains where the boundaries of organizations (e.g., geographical, product-related, cultural) lie and how they shift in response to changes in conditions. Its application to multinational enterprises is just one of many applications of the internalization principle. The principle of internalization itself is based on transaction-cost theory, which states that transactions are made within an organization if the transaction costs on the free market are higher than the internal costs (Buckley and Casson, 2009; tinyurl.com/9coq99s).

The ownership-location-internalization (OLI) model brings together several theories of international economics into one approach to explain exports, foreign direct investments, and licensing.

The key messages of internalization theory include:

1. The uni-national company is simply a special case of the multinational company; the size of the uni-national company is limited by the size of the home market. 


\section{What Technology Startups Must Get Right to Globalize Early and Rapidly}

\section{Tony Bailetti}

2. Invest in the creation of new knowledge and the commercial applications of new knowledge.

3. Locate each activity where it results in the lowest cost including the costs of linking it into other activities.

4. Expand into foreign markets where the incremental benefits of further internationalization offset the incremental costs.

The key messages of the OLI model are:

1. Leverage, shape, and create ownership, location, and internalization advantages. Ownership advantages can be derived from reputation, trademarks and patents, production processes, specialized skills, and returns to scale. Location advantages refer to a region's advantages due to the existence of raw materials, low wages, special taxes, etc. Internalization advantages refer to advantages gained when the company undertakes the activity internally instead of externally via partnership arrangements.

2. Link internal strengths with external opportunities.

3. Decisions to expand abroad rather than domestically are determined by the opportunities identified by top managers and their links to the startup's ownership advantages.

4. Decisions about foreign locations in which to establish value-added activities are determined by the perceived match between opportunities and the advantages of the location.

5. Growth through foreign expansion is driven by the availability of excess resources and services they provide.

\section{Propositions for Globalizing a Technology Startup Early and Rapidly}

The lessons learned from examining the literature can be applied to the globalization of technology startups from inception. These lessons can be organized in terms of what managers need to do to globalize a technology startup early and rapidly, as follows.

\section{Acquire and deploy knowledge quickly}

To globalize early and rapidly, a technology startup requires knowledge about: i) a problem and its solution that are important to a large and growing number of foreign and domestic organizations; ii) a global market; and iii) how to globalize. We reason that, to acquire and deploy this knowledge quickly, managers of a startup need to: i) embed the startup in the systems that create the knowledge that is critical to its success; ii) engage in the exchange of knowledge, information, and other resources with international contacts; and iii) adjust to changes in knowledge required in terms of knowledge classification, function, network composition, and interaction patterns

\section{Secure commitments to act jointly and quickly}

There are five ways to secure stakeholders' commitments to act jointly and quickly. First, the managers of the startup need to interact with customers and partners in lead positions in the global market who have technology knowledge that overlaps with the startup's technology knowledge. Second, the startup needs to search out and mobilize individuals and organizations with specialized knowledge that are scattered around the world. Third, managers need to develop a vision for the commercialization of knowledge-intensive, novel, and differentiable products. Four, the startup needs to quickly deliver value to potential customers and partners. Fifth, the startup needs to target large customers and partners with global reach whose requirements can be satisfied quickly and expose the startup to low risk of channel conflicts

\section{Use the Internet}

A few studies suggest that a startup should use the Internet to market the startup's products and services. Etemad, Wilkinson, and Dana (2010; tinyurl.com/dytugq2) consider the Internet as the necessary condition for internationalization. The Internet provides collaboration tools, payment mechanisms, a foundation for building and delivering products, and many other value-creating processes.

\section{Build relational capital}

The literature suggests that the relationships humans have are a more important capital to the startup than the humans themselves. Strong relational capital increases collaboration with others. To build relational capital, the literature suggests that the startup's management team should proactively leverage new and existing networks to locate and interact with potential customers, partners, and suppliers.

\section{Gain legitimacy}

The literature suggests that the startup should increase legitimacy by: i) establishing presence in key markets, ii) gaining high-profile endorsements from established 


\section{What Technology Startups Must Get Right to Globalize Early and Rapidly}

\section{Tony Bailetti}

companies, iii) leveraging mentors and advisors to build an ecosystem around the startup, and iv) participating in high-profile activities related to direct foreign investment.

\section{Strengthen global capability}

To strengthen capability to service customers and partners regardless of where they are located, the literature suggests that managers need to: i) link the internal strengths of the startup directly with the definition and exploitation of global opportunities; ii) increase their global competences, vision, risk taking, cross-border networks, and awareness of foreign growth opportunities; iii) leverage, shape, and create ownership, location, and internalization advantages; and iv) shed domestic rigidities for the purpose of exploiting new global opportunities.

\section{Identifying Startups that Increased Foreign Sales Early and Rapidly}

Researchers have used various criteria to find startups that increased their sales early and rapidly (Gabrielsson and Kirpalani, 2012; tinyurl.com/cnmtekt). The criteria used in this article focused on two dimensions of internationalization: company precocity (time before first sale) and company speed (percentage of foreign sales at a given age). We were not concerned about the startups that were large-company spinoffs or joint ventures of large companies; thus, they were excluded.

To be included in the sample, a startup had to meet the following criteria:

\section{Founded between 2002 and 2009}

2. First foreign sale in the first year of operations

3. Foreign sales at least half of total sales by the third year of operations

4. Independent operation during its first three years (i.e., the startup could not have been acquired during this period)

The Google search utility (google.com) was used to identify web pages containing: i) "born global", ii) "export award winner", or iii) phrases that combined "fast growing" or "fast export" with the words "startup", "company", and "firm". A list of the companies identified by the web searches was compiled. For each company on the list, information about the company published on its website or in press releases, association journals, and news announcements was examined to decide whether or not the company met the criteria identified above.

\section{Search Results}

The search was conducted in the summer of 2012, and it identified 21 startups founded in 12 countries between 2002 and 2009. The market offers of these startups were organized into four types: cloud computing services, software products, software services, and industrial products.

For each startup, Table 1 identifies its initial market offer, offer type, country of origin, and year founded. The sample includes startups that design, develop, and manufacture technology internally, depend on the technology supplied by others, develop software products and tools, deliver web-based specialized services, and provide custom software services.

The 21 startups were founded in 12 countries. Of the 21 startups, nine (43\%) were founded in six European countries (Cyprus, Czech Republic, Denmark, Germany, Sweden, United Kingdom), four in the United States $(19 \%)$, three $(14 \%)$ in Australia, two $(10 \%)$ in South America, two (10\%) in Israel, and one (4\%) in China. Nine $(43 \%)$ of the 21 startups in Table 1 were founded between 2002 and 2005, and 12 (57\%) were founded between 2006 and 2009.

Of the 21 technology startups included in the sample, 11 (52\%) offered web-based services, five $(24 \%)$ developed and sold software, three (14\%) designed, developed, and manufactured industrial products, and two $(10 \%)$ delivered software services.

\section{Findings from Examining Company Information}

The publically available information on the 21 startups shown in Table 1 was examined. The three main findings are described in this section.

\section{Startups addressed a problem that was pervasive globally}

Table 1 suggests that each of the startups that increased foreign sales early and rapidly addressed a problem that affected a large and growing number of organizations and individuals in various geographies. 


\section{What Technology Startups Must Get Right to Globalize Early and Rapidly}

\section{Tony Bailetti}

Table 1. Companies found to have rapidly increased foreign sales within three years from inception

\begin{tabular}{|c|c|c|c|c|c|}
\hline & Company & Market Offer & Offer Type & Country of Origin & $\begin{array}{c}\text { Year } \\
\text { Founded }\end{array}$ \\
\hline 1 & $\begin{array}{l}\text { 360Cities } \\
\text { 360cities.net }\end{array}$ & Geo-referenced panoramic photos & $\begin{array}{l}\text { Web-based } \\
\text { service }\end{array}$ & Czech Republic & 2007 \\
\hline 2 & $\begin{array}{l}\text { Airbnb } \\
\text { airbnb.com }\end{array}$ & Marketplace for unique accommodations & $\begin{array}{l}\text { Web-based } \\
\text { service }\end{array}$ & United States & 2008 \\
\hline 3 & $\begin{array}{l}\text { Ansarada } \\
\text { ansarada.com }\end{array}$ & Virtual data rooms & $\begin{array}{l}\text { Web-based } \\
\text { service }\end{array}$ & Australia & 2005 \\
\hline 4 & $\begin{array}{l}\text { Atlassian } \\
\text { atlassian.com }\end{array}$ & Software development and collaboration tools & Software & Australia & 2002 \\
\hline 5 & $\begin{array}{l}\text { Canonical } \\
\text { canonical.com }\end{array}$ & $\begin{array}{l}\text { Commercial support and services for Ubuntu } \\
\text { Linux and related projects }\end{array}$ & $\begin{array}{l}\text { Software } \\
\text { services }\end{array}$ & United Kingdom & 2004 \\
\hline 6 & $\begin{array}{l}\text { Conduit } \\
\text { conduit.com }\end{array}$ & Tools that enable publishers to interact with users & $\begin{array}{l}\text { Web-based } \\
\text { service }\end{array}$ & Israel & 2005 \\
\hline 7 & $\begin{array}{l}\text { Dewak S.A. } \\
\text { dewak.com }\end{array}$ & Help desk products and services & $\begin{array}{l}\text { Software } \\
\text { services }\end{array}$ & Colombia & 2008 \\
\hline 8 & $\begin{array}{l}\text { Dropbox } \\
\text { dropbox.com }\end{array}$ & $\begin{array}{l}\text { File hosting service for photos, documents, and } \\
\text { videos }\end{array}$ & $\begin{array}{l}\text { Web-based } \\
\text { service }\end{array}$ & United States & 2007 \\
\hline 9 & $\begin{array}{l}\text { Eagleyard Photonics } \\
\text { eagleyard.com }\end{array}$ & $\begin{array}{l}\text { High-power laser diodes for medical, scientific, } \\
\text { and industrial applications }\end{array}$ & $\begin{array}{l}\text { Industrial } \\
\text { products }\end{array}$ & Germany & 2002 \\
\hline 10 & $\begin{array}{l}\text { eToro } \\
\text { etoro.com }\end{array}$ & $\begin{array}{l}\text { Social investment network for currencies, } \\
\text { commodities, and indices }\end{array}$ & $\begin{array}{l}\text { Web-based } \\
\text { service }\end{array}$ & Cyprus & 2007 \\
\hline 11 & $\begin{array}{l}\text { GoodData } \\
\text { gooddata.com }\end{array}$ & Business intelligence solutions & Software & Czech Republic & 2007 \\
\hline 12 & $\begin{array}{l}\text { GPEG } \\
\text { gpegint.com }\end{array}$ & $\begin{array}{l}\text { Displays for industrial, gaming, professional, and } \\
\text { consumer markets }\end{array}$ & $\begin{array}{l}\text { Industrial } \\
\text { products }\end{array}$ & United Kingdom & 2005 \\
\hline 13 & $\begin{array}{l}\text { Griaule Biometrics } \\
\text { griaulebiometrics.com }\end{array}$ & $\begin{array}{l}\text { Software development kits to develop biometric- } \\
\text { based applications }\end{array}$ & Software & Brazil & 2002 \\
\hline 14 & $\begin{array}{l}\text { Groupon } \\
\text { groupon.com }\end{array}$ & Discounted gift certificates & $\begin{array}{l}\text { Web-based } \\
\text { service }\end{array}$ & United States & 2008 \\
\hline 15 & $\begin{array}{l}\text { Mojang } \\
\text { mojang.com }\end{array}$ & Video games & Software & Sweden & 2009 \\
\hline 16 & $\begin{array}{l}\text { Noja Power } \\
\text { nojapower.com.au }\end{array}$ & $\begin{array}{l}\text { Medium voltage recloser products and low-voltage } \\
\text { motor control centre switchboards }\end{array}$ & $\begin{array}{l}\text { Industrial } \\
\text { product }\end{array}$ & Australia & 2002 \\
\hline 17 & $\begin{array}{l}\text { Papaya Mobile } \\
\text { papayamobile.com }\end{array}$ & Games on a social platform & $\begin{array}{l}\text { Web-based } \\
\text { service }\end{array}$ & China & 2008 \\
\hline 18 & $\begin{array}{l}\text { Sellaband } \\
\text { sellaband.com }\end{array}$ & $\begin{array}{l}\text { Crowdfunding for the purpose of recording } \\
\text { professional albums }\end{array}$ & $\begin{array}{l}\text { Web-based } \\
\text { service }\end{array}$ & Germany & 2006 \\
\hline 19 & $\begin{array}{l}\text { Sproxil } \\
\text { sproxil.com }\end{array}$ & $\begin{array}{l}\text { Authentication solutions using short message } \\
\text { service for mobile phones }\end{array}$ & $\begin{array}{l}\text { Web-based } \\
\text { service }\end{array}$ & United States & 2008 \\
\hline 20 & $\begin{array}{l}\text { Tufin } \\
\text { tufin.com }\end{array}$ & Network security products and solutions & Software & Israel & 2005 \\
\hline 21 & $\begin{array}{l}\text { Zendesk } \\
\text { zendesk.com }\end{array}$ & Platform to manage customer service responses & $\begin{array}{l}\text { Web-based } \\
\text { service }\end{array}$ & Denmark & 2007 \\
\hline
\end{tabular}




\section{What Technology Startups Must Get Right to Globalize Early and Rapidly}

\section{Tony Bailetti}

\section{Collaborative entrepreneurial processes drive early and rapid foreign sales}

Recently, the rapid internationalization of startups has been conceptualized as the outcome of an entrepreneurial process at the individual level. However, at least partly, seven of the startups in Table 1 (360Cities, Airbnb, Canonical, eToro, Groupon, Papaya Mobile, and Sellaband) increased their foreign sales rapidly because they delivered shared services to a global, large-scale, multi-party community that enabled different actors to act entrepreneurially.

Consider the case of 360Cities. This startup maintains the web's largest collection of geo-referenced panoramic photos created by a network of thousands of expert photographers from around the world. The company increased its foreign sales rapidly because it enabled hundreds of professional photographers worldwide to act entrepreneurially and collaborate with: i) large companies (e.g., Google, Microsoft, Nokia, and Flipboard) that operate mapping platforms for the purpose of providing location-based services; ii) advertising agencies, publishers, application developers, and travel industry service providers who license content for use online and in mobile and tablet devices; and iii) digital marketers, venue owners, and team managers who undertake projects to support large events.

Airbnb enables landlords to act entrepreneurially. The startup provides a marketplace that enables people to take vacations in other people's homes, apartments, boats, castles, islands, and cabins. Landlords increase their income by continuously renting extra space effortlessly and increase their listing's exposure in a pre-built community. Travellers are the customers who compare options and interact with landlords to leverage their funds as much as possible.

Canonical works with the open source community to deliver Ubuntu, and it sells enterprise, engineering, and consumer services. Ubuntu is a free operating system that powers millions of desktops, netbooks, and servers around the world. More than 20 million people use Ubuntu servers, and 22 thousand new websites a month are built on Ubuntu servers. Canonical and a network of independent software vendors, resellers, and original equipment manufacturers leverage the Ubuntu code to generate revenue. Canonical, which was founded in 2004, has staff in more than 30 countries and has offices in London, Boston, Taipei, Montreal, Shanghai, São Paulo, and the Isle of Man.
Fjeldstad, Snow, Miles, and Lettl (2012; tinyurl.com/94czk7f) identify three elements of an actororiented scheme that anchors collaborative entrepreneurship: actors, common resource, and protocols for collaboration. These three elements can be observed in the seven startups that are in this group. First, each startup attracts actors from all over the world (i.e., companies and individuals) who can self organize and engage in collaborative relationships. Second, each startup maintains a common resource that evolves as the actors engage with one another. The commons of the seven startups include: collection of panoramic photos, code of a complex software system, listings of properties for rent, trade strategies, local and national deals, multi-party games, and new music projects. Third, each startup maintains the protocols, processes, and infrastructures that enable collaboration.

\section{Web processes provide important support to startups' early and rapid foreign sales}

Of the 21 startups shown in Table 1, 18 (86\%) generate their revenue from the sale of digital goods and services (i.e., web-based services, software products, and software services). It would be difficult to explain the rapid internationalization of these 18 startups without describing how they relied on the World Wide Web and its underlying electronic communications structure, the Internet, to create and deliver value to their foreign customers, suppliers, and partners. Table 2 illustrates how the startups included in Table 1 use the Internet.

Eleven of the startups in the sample provide web-based services. These services automate manual processes (Airbnb, Groupon), create new ways for people to interact (Conduit, eToro), provide tools for small companies and consumers to leverage the web (360Cities, Ansarada, Dropbox, Papaya Mobile, Sellaband, Sproxil), and provide tools for large enterprises to leverage the web (Zendesk).

The information in Table 2 illustrates that the startups that internationalized rapidly adopted and deployed a wide array of innovative web-based processes. These processes linked external value-creating actors around the world to the internal processes of the company in very innovative ways, deployed innovations not offered previously, and enabled the company to innovate on a continuous and efficient basis.

Consider Tufin, a network security company that specializes in the management of next-generation and net- 


\section{What Technology Startups Must Get Right to Globalize Early and Rapidly}

Tony Bailetti

Table 2. How startups that grew foreign sales rapidly in the first three years use the Internet

\begin{tabular}{|c|c|c|}
\hline & Internet Uses & Examples \\
\hline 1 & $\begin{array}{l}\text { Distribute content about products, services, } \\
\text { and company, newsletters, and press releases }\end{array}$ & - All 21 startups \\
\hline 2 & $\begin{array}{l}\text { Provide free access to specialized facilities and } \\
\text { individuals }\end{array}$ & $\begin{array}{l}\text { - GPEG provides online access to its Technology Showcase located in } \\
\text { London and to its engineering team } \\
\text { GoodData provides free access to all features and connectors to other } \\
\text { applications and user support }\end{array}$ \\
\hline 3 & $\begin{array}{l}\text { Make available downloadable software, which } \\
\text { is free to use for a limited period and which } \\
\text { allows a potential customer to do virtual } \\
\text { product testing }\end{array}$ & - Atlassian, Griaule Biometrics, Tufin \\
\hline 4 & Schedule demonstrations of startup's offer & - Tufin \\
\hline 5 & Sell via an online store & - Atlassian, Griaule Biometrics, Mojang \\
\hline 6 & $\begin{array}{l}\text { Locate customers, exchange product } \\
\text { development information, develop product, } \\
\text { and deliver service support }\end{array}$ & $\begin{array}{l}\text { Dewak S.A. finds customers on online forums and blogs, exchanges } \\
\text { information required to develop custom solutions, and provides post-sales } \\
\text { services }\end{array}$ \\
\hline 7 & $\begin{array}{l}\text { Deliver hosting services to consumers and } \\
\text { small organizations and allow users to interact }\end{array}$ & $\begin{array}{l}\text { - Dropbox allows users to bring their photos, documents, and videos } \\
\text { anywhere and share them easily } \\
\text { - Groupon offers a deal-of-the-day website that features discounted gift } \\
\text { certificates usable at local or national companies }\end{array}$ \\
\hline 8 & $\begin{array}{l}\text { Deliver hosting services to enterprises for the } \\
\text { purpose of improving productivity }\end{array}$ & $\begin{array}{l}\text { - Ansarada provides groups access to virtual data rooms that are simple and } \\
\text { intuitive to use } \\
\text { - Conduit provides tools that enable publishers to engage with their users } \\
\text { - Zendesk allows enterprises to manage customer service responses }\end{array}$ \\
\hline 9 & Develop open source software and sell services & $\begin{array}{l}\text { - Canonical leads co-development of Ubuntu and sells engineering services } \\
\text { to enterprises and original equipment manufacturers }\end{array}$ \\
\hline 10 & $\begin{array}{l}\text { Crowdsource, receive feedback, and increase } \\
\text { brand recognition }\end{array}$ & $\begin{array}{l}\text { 360Cities maintains the web's largest collection of geo-referenced } \\
\text { panoramic photos, created by thousands of expert panorama } \\
\text { photographers }\end{array}$ \\
\hline 11 & $\begin{array}{l}\text { Crowdfund, receive feedback, and increase } \\
\text { brand recognition }\end{array}$ & $\begin{array}{l}\text { - Sellaband allows artists to raise money from their fans and a SellaBand } \\
\text { community for the purpose of recording a professional album }\end{array}$ \\
\hline 12 & $\begin{array}{l}\text { Engage millions of game users and enable } \\
\text { social media interactions }\end{array}$ & $\begin{array}{l}\text { Papaya Mobile allows game developers to reach more than } 50 \text { million } \\
\text { mobile device users }\end{array}$ \\
\hline 13 & $\begin{array}{l}\text { Operate a market exchange and enable social } \\
\text { media interactions }\end{array}$ & $\begin{array}{l}\text { - eToro operates an electronic marketplace to trade currencies, } \\
\text { commodities and indices } \\
\text { - Airbnb operates a marketplace to rent accommodation from people in } \\
\text { more than } 30,000 \text { cities in } 192 \text { countries }\end{array}$ \\
\hline 14 & Deliver product authentication services & - Sproxil provides product authentication solutions to mobile users \\
\hline 15 & Deliver training & - Atlassian, GoodData, Noja Power \\
\hline 16 & $\begin{array}{l}\text { Register and support partners as well as } \\
\text { reduce potential for fines and mandatory } \\
\text { audits }\end{array}$ & $\begin{array}{l}\text { - Tufin's programs that support channel, development, and technology } \\
\text { alliances }\end{array}$ \\
\hline 17 & Manage material returns & - Eagleyard analyses product failures and manages returns of materials \\
\hline
\end{tabular}




\section{What Technology Startups Must Get Right to Globalize Early and Rapidly}

\section{Tony Bailetti}

work-layer firewalls, routers, network switches, and other network security devices. The company has been cash-flow positive since its inception in 2005. Tufin's rapid international growth is the result of its use of the Internet, making it easy for partners to sell Tufin's products. Their partners include network security vendors that include Cisco, Check Point, Juniper Networks, Fortinet, BMC, Palo Alto Networks, Blue Coat, F5 Networks, and 240 others.

Small companies such as Ansarada, Dropbox and Sproxil use the web and other communication technologies to deliver cloud-based services to customers globally.

Large and small companies around the world are able to outsource important functions to startups. Consider Zendesk, one of the fastest-growing startups examined in the study, which was founded in Denmark. Zendesk helps enterprises of all sizes worldwide to better manage their responses to customers.

The three startups in Table 1 that designed and manufactured physical products also rely on web-based processes to add value to their customers, suppliers, and partners. Eagleyard uses the web to better manage returns of materials. GPEG uses the web to allow developers of devices that use displays to access its Technology Showcase located in London. Noja Power uses the web to deliver videos that educate users on how smart grids and their products function.

The information in Table 2 strongly suggests that webbased processes are very much a part of the value-creation processes for the great majority of the startups found to increase foreign sales rapidly from inception. Thus, it is time for scholars to explicitly integrate webbased processes into the models that explain rapid globalization from inception.

This represents a significant knowledge gap. However, the incorporation of web-based processes into rapid internationalization models presents a serious challenge to scholars in international business. Extant models on company internationalization were first developed by observing experiences of large companies in the real world. But, in order to understand rapid globalization from inception, we need to incorporate observations of experiences of startups that were born on the web and benefit from web-savvy management teams. The real world's traditional perceptions of time, space, speed, quality, structure, and power do not map nicely into the invisible spaces that exist on the web. For example, the many lessons that have been painstakingly learned in the past, that focused on the real world (e.g., cross cultural-studies, market entry, market expansion) may not directly apply in cyberspace, and the pertinent theoretical models must be updated to take this into account.

\section{Lessons for Early and Rapid Internationalization}

Examination of the lessons learned from the literature review and from examining the information on the companies in the sample led the author to propose that there are six elements that management teams and their investors must get right to internationalize their startups early and rapidly. These elements are:

1. Problem scope: knowledge about a question and its answer that are important to a large and growing number of foreign and domestic organizations

2. Stakeholders' commitments to develop a novel, narrow, and differentiated solution quickly: pledges to work with the startup to rapidly develop the core of the solution for which customers worldwide will pay, provide feedback, and make referrals

3. Collaborative entrepreneurship at a global scale: webbased processes, transportation infrastructure, and common resources that enable individuals and organizations worldwide to act on business opportunities

4. Relational capital: relationships that increase capacity to collaborate quickly with individuals, companies, and institutions around the world

5. Legitimacy: quality of being believable or trustworthy in the eyes of customers, partners, suppliers and investors

6. Global capability: adaptability to uncertain environments and willingness to change for the purpose of delivering products and support programs to customers and partners regardless of where they are located

\section{Conclusion}

In this article, key messages were extracted from six literature streams relevant to the globalization of technology startups. Then, the lessons were organized in terms of what managers need to do to globalize a technology startup early and rapidly. Three lessons learned 


\section{What Technology Startups Must Get Right to Globalize Early and Rapidly}

\section{Tony Bailetti}

from examining the information on a sample of 21 startups found to have increased foreign sales early and rapidly were described, and the six elements of the architecture for the rapid globalization of a technology startup were proposed.

The implications of the findings reported in this article may be significant for three reasons. Firstly, web space is nothing like physical space. If the Internet is indeed a major driver of early and rapid globalization, how relevant is what we teach today about the challenges posed by home-host diversity to management teams of startups?

Secondly, international entrepreneurship is a growing area of research. To explain early and rapid entrepreneurship, scholars have creatively used bricolage principles to construct concepts from a diverse range of abstractions published in the entrepreneurship, international, and strategic management journals. What is becoming increasingly common is the focus on the entrepreneur at the individual level and objective opportunity at the company level. Results in this study suggest that collective entrepreneurship may be a better abstraction than the conventional "entrepreneur at the individual level" abstraction. We find instances where startups grow rapidly because they link suppliers, customers, and partners in ways that enable them all to act entrepreneurially. We also find that a portfolio of ever-changing opportunities may be a better abstraction than the conventional "one objective opportunity" abstraction.
Thirdly, the approaches and models that can help startups meet the requirements of global markets from inception need to be developed and validated empirically, enacted by startups' management teams, and evolved by incorporating the lessons learned from using them.

The main motivation for writing this article was to highlight the need to develop norms and practitioner-oriented models that can help technology startups better manage their early and rapid globalization. We hope that researchers will increasingly focus their attention on the development of approaches and models that can assist management teams internationalize their startups early and rapidly.

\section{About the Author}

Tony Bailetti is an Associate Professor in the Sprott School of Business and the Department of Systems and Computer Engineering at Carleton University, Ottawa, Canada. Professor Bailetti is the Director of Carleton University's Technology Innovation Management program (carleton.ca/tim). His research, teaching, and community contributions support technology entrepreneurship, regional economic development, and international co-innovation.

Citation: Bailetti, T. 2012. What Technology Startups

Must Get Right to Globalize Early and Rapidly. Technology (cc) BY Innovation Management Review. October 2012: 5-16. 


\section{What Technology Startups Must Get Right to Globalize Early and Rapidly}

Tony Bailetti

Appendix A. References examined to generate lessons learned, by literature stream

\section{Rapid internationalization}

- Bangara, Freeman, and Schroder (2012; tinyurl.com/d98kovc)

- Chandra, Styles, and Wilkinson (2012; tinyurl.com/blaqf7r)

- Freeman, Hutchings, Lazaris, and Zyngier (2010; tinyurl.com/blcjo2s)

- Freeman and Cavusgil (2007; tinyurl.com/d4l5qe2)

- Gabrielsson and Kirpalani (2004; tinyurl.com/94wdjwo)

- Prashantham and Young (2009; tinyurl.com/d22vj4e)

- Styles and Genua (2008; tinyurl.com/ces23su)

- Vermeulen and Barkema (2002; tinyurl.com/cx5mvb4)

-Weerawardena, Sullivan Mort, Liesch, and Knight (2007; tinyurl.com/ctm63tg)

\section{International new venture}

- Autio (2005; tinyurl.com/cw6ofxs)

- Li (2010; tinyurl.com/bsclbjf)

- McDougall and Oviatt (2000; tinyurl.com/745yv3v)

- Oviatt and McDougall (1994; tinyurl.com/csmj5n8)

- Oviatt and McDougall (1995; tinyurl.com/ceekw4l)

- Oviatt and McDougall (1997; tinyurl.com/c2qmbko)

\section{Effectuation}

- Andersson (2011; tinyurl.com/btt8w7y)

- Harms and Schiele (2012; tinyurl.com/buqpkzj)

- Kalinic, Sarasvathy, and Forza (2012; tinyurl.com/cj84gk6)

4. Global startups

- Doz and Wilson (2012; tinyurl.com/bl5udjz)

- Doz, Santos, and Williamson (2001; tinyurl.com/ca9cdbz)

- Englis, Wakkee, and Van Der Sijde (2007; tinyurl.com/c4boo73)

\section{Gradual internationalization process models}

- Eriksson, Johanson, Majkgard, and Sharma (1997; tinyurl.com/155258)

- Johanson and Wiedersheim-Paul (1975; tinyurl.com/ck5a6t3)

- Johanson and Vahle (1977; tinyurl.com/d2aafbo)

- Johanson and Vahle (1990; tinyurl.com/cb3m98k)

- Johanson and Vahle (2009; tinyurl.com/bv8nbej)

- Luostarinen (1979; tinyurl.com/d8qmbgl)

- Steen and Liesch (2007; tinyurl.com/dxvk4op)

6. Internalization theory of the multinational enterprise and the OLI model

- Buckley and Casson (2003; tinyurl.com/crlcmj4)

- Buckley and Casson (2009; tinyurl.com/9coq99s)

- Dunning (2000; tinyurl.com/c8xgcfm)

- Dunning (2001; tinyurl.com/cy2r5nf)

- Pitelis (2007; tinyurl.com/ckxv4lt) 